Al-Bayyinah: Journal of Islamic Law-ISSN: 1979-7486 (p); $\underline{2580-5088}$ (e) Volume VI Number 2, pp. 1-16

\title{
PERKAWINAN BEDA AGAMA DALAM PERSPEKTIF HADIS AHKAM
}

\section{Muhammad Farid}

(Dosen Tetap STAIN Watampone, Sulawesi Selatan, Indonesia, email:muhammadfarid@gmail.com)

\section{Abstract}

Ideal marriage in Islam cover both physical and psyche aspects. Specially in psyche spectrum, the same in a belief is a main stream. Islam always warns to the all Muslims not to marry a follower of the different religion. Cause if it does the for bidden, the next: main target of marriage, namely life in loving and happy each other, it won't be fulfilled except one the converts. If it converts to Islam, it may be not a problem, but if one of them out of Islam, it is a really case. So syariat Islam warns to marry with the one of the similarity life ideologi, and it will be explain in the next item.

Kata Kunci: Perkawinan, beda agama, hadis ahkam, konversi dan ijtihad ulama

\section{PENDAHULUAN}

Manusia adalah makhluk ciptaan Tuhan yang mulia, yang terdiri atas laki-laki dan perempuan. Pada keduanya dianugerahi kecenderungan untuk mencintai. Allah juga memberikan sarana untuk mengekspresikan rasa cinta tersebut yaitu pernikahan.

Pernikahan yang baik adalah pernikahan yang dilakukan pria dan wanita yang sama akidah, akhlak dan tujuannya, di samping cinta dan ketulusan hati. Dengan keterpaduan itulah, kehidupan suami istri akan tenteram, penuh cinta dan kasih sayang. Keluarga akan bahagia dan anak-anak akan sejahtera. 
Kehidupan keluarga seperti itu sulit akan terwujud secara sempurna kecuali jika suami istri berpegang kepada agama yang sama. Jika agama keduanya berbeda, akan timbul berbagai kesulitan di lingkungan keluarga, dalam pelaksanaan ibadah, pendidikan anak, pengaturan makanan, tradisi keagamaan, dan lain-lain.

Beberapa ayat al-Qur'an mengatur dengan tegas tentang perkawinan antara umat Islam dan non-Islam, baik antara laki-laki muslim dengan non muslim atau sebaliknya. ${ }^{1}$ Agaknya ini pulalah yang menyebabkan sedikitnya hadis Rasul saw. yang menjelaskan hal tersebut. Di antara hadis tersebut adalah:

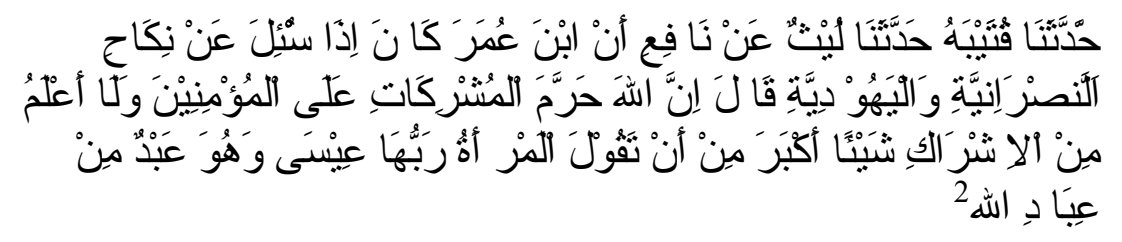

Artinya:

"Telah menceritakan kepada kami Qutaibah, telah menceritakan kepada kami al-Laits dan Nafi' menceritakan bahwa Ibn Umar ketika ditanya tentang menikahi wanita Nasrani dan Yahudi, ia menjawab: sesungguhnya Allah telah mengharamkan wanita-wanita musyrik bagi kaum muslimin dan aku tidak tahu syirik manakah yang lebih besar daripada seorang perempuan yang berkata Tuhannya adalah Isa, sedangkan Isa adalah salah seorang diantara hamba Allah.” H. R. Bukhari.

Berdasarkan hadis di atas penulis akan mengelaborasi melalui pendekatan metode hadis ahkam. ${ }^{3}$ Sehingga jelas akan

${ }^{1}$ Diantara yang diatur oleh al-Qur'an adalah (1) Larangan melangsungkan pernikahan antara laki-laki muslim dengan wanita musyrik atau sebaliknya (QS) al-Baqarah (2): 221, (2) Kebolehan menikahi wanita ahl al-kitab (QS. al-Maidah (5): 5).

${ }^{2}$ Al-Bukhari, Shahih al-Bukhari (Beirut: Dar al-Fikr, 1994), h. 211.

${ }^{3}$ Minimal ada lima metode atau langkah untuk menetapkan hukumhukum yang dapat diambil dari hadis yang sedang dibicarakan, yaitu: (1)Menjelaskan makna kata yang penting, baik menurut bahasa maupun menurut istilah fikih; (2) Melihat dan menentukan cakupan pengertian lahir 
makna dan kandungan hadis tersebut sesuai dengan hukum Islam.

\section{PEMBAHASAN}

\section{A. Makna Mufradat}

Dari hadis di atas ada beberapa kata yang harus diuraikan maknanya, yaitu:

نكاح yang secara bahasa berarti berkumpul atau menindas dan saling memasukkan. ${ }^{4}$ Sedangkan secara terminologi, ahli fikih dan ushul fikih berbeda pendapat tentang definisi nikah. Menurut ulama Hanafiah, nikah adalah akad yang menghalalkan hubungan kelamin antara pria dan wanita. Adapun menurut ulama Syafi'iyah, nikah adalah akad yang menghalalkan hubungan kelamin antara pria dan wanita dengan lafal nikah atau yang semakna dengannya. ${ }^{5}$

kata ini menunjuk kepada pemeluk agama Nasrani (Kristen) yaitu agama yang diturunkan kepada bani Israil melalui Nabi Isa as.

Mengenai asal kata al Nashraniyyah atau nashara terdapat beberapa versi, yaitu:

1. Berasal dari kata nashara yang berarti menolong atau membantu. Dikatakan demikian karena mereka memberikan pertolongan kepada orang lain atau saling membantu diantara mereka.

2. Sebutan nashara atau nasrani dikaitkan dengan daerah asal keluarga Nabi Isa as., yang bernama Nashiri. Al-Baghdadi menyatakan bahwa Nashiri adalah tempat kelahiran Nabi Isa as., akan tetapi pendapat yang populer, terutama di kalangan

hadis berdasarkan makna mufradat (tunggal) tana menakwilkannya; (3) Mengemukakan pendapat ulama lengkap dengan argumennya sebagai bahan pertimbangan; (4) Mencari illat sepanjang dapat ditemukan; dan (5) Menyimpulkannya. Lihat Abdul Aziz Dahlan (et.al), Ensiklopedi Hukum Islam (Jakarta: PT Ichtiar Baru Van Houve, 1997), h. 425.

${ }^{4}$ Muhammad ibn Ismail al-kahlani al-Shan'ani, Subul al-Salam (Riyad: al-Jami'ah al-Imam Muhammad ibn Su'ud al-Islamiyah, 1408 H), h. 173 . tt.), h. 20-21.

${ }^{5} \mathrm{Abu}$ al-Ainain Bdran, al-Zawaj wa al-Thalaq fi al-Islam (Kairo: tp., ${ }^{6}$ Al-Thabari, Tafsir al-Thabari (Beirut: dar al-Fikr, 1984), h. 144. 
orang-orang Nasrani, memang keluarga Nabi Isa as., berasal dari Nashiri, tetapi beliau sendiri lahir di Bethlehem. ${ }^{7}$

3. Sebutan nashara atau Nasrani dikaitkan dengan pertanyaan Nabi Isa as., kepada orang-orang Hawari tentang kesediaan mereka berjuang di jalan Allah bersama beliau. ${ }^{8}$ Pendapat ini berdasarkan firman Allah pada QS. Al-Shaff (61): 14

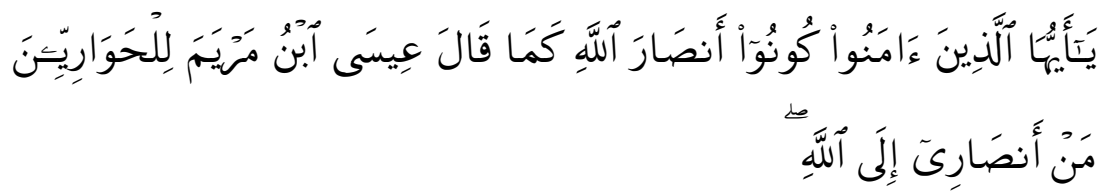

Terjemahnya:

Hai orang-orang yang beriman, jadilah kamu penolong (agama) Allah sebagaimana Isa ibnu Maryam telah berkata kepada pengikut-pengikutnya yang setia: "Siapakah yang akan menjadi penolong-penolongku (untuk menegakkan agama) Allah?" pengikut-pengikut yang setia itu berkata: "Kamilah penolong-penolong agama Allah". 9

Meskipun terdapat perbedaan pendapat mengenai asal kata nashara atau nashrani, tetapi pada dasarnya terdapat persamaan atau setidaknya dapat saling melengkapi. Di samping kata tersebut dikaitkan dengan tempat atau daerah asal Isa as., dapat juga dikaitkan dengan perilaku pengikut-pengikut setia beliau yang bahu-membahu dan tolong-menolong serta tekad bulat untuk berjuang menegakkan kebenaran di jalan Allah, seperti yang terkandung dalam pengertian dasar kata nashara.

kata ini ditujukan kepada komunitas penganut agama Yahudi. Kata tersebut berasal dari kata haaduu (kata kerja bentuk lampau) yang secara literal berarti kembali secara perlahan-lahan, bersuara lembut, dan berjalan dengan merangkak. Kata ini juga lazim diartikan dengan taubat. ${ }^{10}$

${ }^{7}$ J. H. Bavick, Sejarah Kerajaan Allah, pent. A. Simanjuntak (Jakarta: BPK Gunung Mulia, 1990), h. 41.

${ }^{8}$ Ibid.

${ }^{9}$ Lihat Departemen Agama RI, Al-Qur'an dan Terjemahnya (Semarang: Toha Putra, 1989), h. 930.

10 Al-Raghib al-Ashafani, Al-Mu'jam al-Mufradat al-Alfadz al-Qur'an (Beirut: Dar al-Fikr, tt.), h. 455. 
Mengenai asal kata haaduu, yahuud, atau yahuudiyyah, terdapat banyak versi, diantaranya:

1. Berasal dari kata haada, yang berarti bertaubat atau kembali ke jalan yang benar. Hal ini didasarkan pada firman Allah QS. Al-A'raf (7): 156.

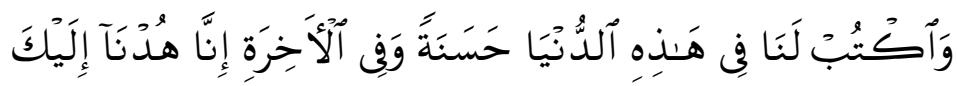

Terjemahannya:

Dan tetapkanlah untuk kami kebajikan di dunia ini dan di akhirat sesungguhnya kami kembali (bertaubat) kepada engkau. ${ }^{11}$

Dikatakan demikian karena mereka (umat Nabi Musa) yang bertaubat dari kesalahannya menyembah anak unta dan kembali kepada kebenaran. ${ }^{12}$

2. Berasal dari perkataan yahuda, dibangsakan kepada yshudza, putra terutama Nabi Yaqub as., kemudian huruf dzal diganti dengan dal, sehingga menjadi yahuda. ${ }^{13}$

3. Disebut Yahudi karena mereka menyimpang dari aturanaturan yang ditetapkan Allah swt., baik aturan yang dibawa Nabi Musa as., maupun yang dibawa Nabi Muhammad saw. Nama ini bersifat pejorative, sebab ia menunjukkan bahwa mereka tidak hanya menolak ajaran yang dibawa Nabi Muhammad saw., yang seharusnya mereka ikuti sesuai dengan tuntutan kitab suci mereka, tetapi juga memberikan isyarat bahwa mereka juga telah menyimpang dari petunjuk kitab sucinya. ${ }^{14}$

4. Disebut Yahudi karena mereka bersikap lemah lembut dan gemetar pada saat membaca kitab suci Taurat. Bahkan ada yang mengatakan bahwa bumi dan langit pun gemetar ketika Allah swt., mewahyukan Taurat kepada Nabi Musa as. ${ }^{15}$

${ }^{11}$ Departemen Agama RI, op. cit., h. 246.

${ }^{12}$ Al-Syaukani, Tafsir Fath al-Qadir (Beirut: Dar Ihya al-Turats alArabiy, tt.), h. 81. tt.), h. 159.

${ }^{13}$ Al-Thabariy, al-Bayan fi al-Tafsir al-Qur'an (Beirut: Dar al-Ma'arif,

${ }^{14}$ Ibid.

${ }^{15}$ Ibid. 
kata ini secara literal berarti orang-orang yang mengsekutukan Allah dengan yang lainnya. Sedangkan secara terminologi musyrik adalah orang-orang yang membuat atau menjadikan sesuatu selain Allah sebagai tambahan, objek

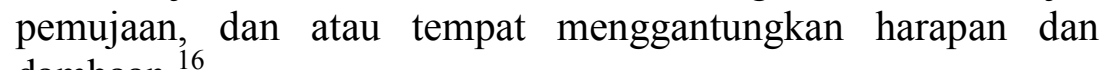
dambaan. ${ }^{16}$

\section{B. Takhrij Hadis}

Hadis di atas hanya diriwayatkan oleh Imam Bukhari. Bila dilihat dari silsilah sanadnya, mulai dari tingkatan sahabat sampai kepada Imam Bukhari, hanya mempunyai satu jalur sanad, sehingga dari segi kuantitasnya hadis ini berstatus ahad gharib. ${ }^{17}$

Unsur ketersendirian yang terdapat dalam hadis ahad gharib seperti dijelaskan di atas bukanlah cacat yang menjadikan suatu riwayat berstatus dha' if (lemah) dan tidak bisa dijadikan hujjah. Hadis ahad gharib adakalanya bernilai shahih, hasan atau dha' if. Hal ini tergantung pada sejauh mana hadis itu memenuhi persyaratan hadis shahih.

Oleh sebab itu, meskipun hadis di atas dari segi kuantitasnya berstatus ahad gharib, tetapi dari segi kualitasnya, hadis tersebut berstatus shahih, karena telah terpenuhinya persyaratan hadis shahih. Oleh sebab itu, hadis tersebut dapat dijadikan hujjah dalam menetapkan hukum, walaupun dalam hal ini masih terdapat perselisihan pendapat di kalangan ulama.

\section{Makna Global Hadis}

Hadis di atas bercerita tentang bagaimana tanggapan Abdullah ibn Umar (10-73 H) yang biasa dikenal dengan Ibn Umar ketika ditanya tentang pernikahan muslim dengan wanita Nasrani atau Yahudi (ahl al-Kitab). Hadis ini diceritakan oleh (disandarkan kepada) Nafi' Maula Ibn Umar (30-117 H). Hadis

\footnotetext{
${ }^{16}$ Harifuddin Cawidu, Konsep Kufr dalam al-Qur'an Suatu Kajian Teologis dengan Pendekatan Tafsir Tematik (Jakarta: Bulan Bintang, 1991), h. 47 .

${ }^{17}$ Hadis Ahad Gharib adalah hadis yang pada satu atau lebih tingkatan sanadnya diriwayatkan oleh satu orang periwayat, M. Hasbi as-Shiddieqy, Pokok-pokok Ilmu Dirayah Hadis (Jakarta: Bulan Bintang, 1987), h. 79.

${ }^{18}$ Subhi Shalih, 'Ulum al-Hadits wa Mushtalahuh (Beirut: dar al-Fikr, 1988), h. 145-146.,
} 
seperti biasa disebut dengan hadis Mauquf, ${ }^{19}$ atau menurut sebagian ulama lain disebut dengan atsar.

Sebagian ulama mengkategorikan hadis mauquf ke dalam kelompok hadis dha'if. Namun sebagian Muhaddisin lainnya, termasuk Subhi al-Shalih mengatakan bahwa hadis mauquf tersebut mungkin saja berstatus shahih. ${ }^{20}$ Hal ini amat tergantung kepada terpenuhi atau tidaknya kriteria keshahihan hadis. Oleh sebab itu, bila hadis tersebut shahih, maka dapat dijadikan hujjah dalam menetapkan hukum.

Hadis di atas merupakan larangan bagi laki-laki Islam untuk menikahi wanita Nasrani atau Yahudi (ahl al-Kitab). Karena dengan ajaran yang mereka anut saat Ibn Umar menyatakan hadis di atas sampai sekarang, yang telah menyimpang dari ajaran aslinya, telah mengeluarkan mereka dari status ahl al-Kitab kepada status musyrik.

\section{Fikih Hadis}

Perkawinan beda agama dapat dikelompokkan kepada dua macam, yaitu (1) Perkawinan antara wanita Islam dengan laki-laki bukan Islam; dan (2) Perkawinan antara laki-laki Islam dengan wanita bukan Islam. Terhadap jenis perkawinan yang pertama, ulama sepakat mengharamkannya. Hal ini didasarkan pada firman Allah swt., dalam QS. Al-Baqarah (2): 221:

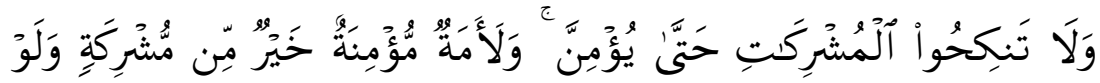

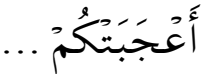

Terjemahnya:

Dan janganlah kamu menikahkan orang-orang musyrik (dengan wanita-wanita mukmin) sebelum mereka beriman. Sesungguhnya budak yang mukmin lebih baik dari orang musyrik, walaupun dia menarik hatimu. ${ }^{21}$

${ }^{19}$ Hadis mauquf adalah hadis yang disandarkan kepada sahabat. Apabila telah sampai kepada sahabat ia (tabi'in) pun berkata: Sahabat itu berkata begini, atau berbuat begini atau menyuruh begini. Lihat, M. Hasbi Ash-Shiddieqy, op. cit., h. 251.

${ }^{20}$ Subhi al-Shalih, op cit., h. 241.

${ }^{21}$ Departemen Agama RI, op. cit., h. 54. 
Kitab Allah pada ayat di atas ditujukan kepada para wali untuk tidak menikahkan wanita Islam dengan laki-laki bukan Islam. Keharamannya bersifat mutlak, artinya wanita Islam haram secara mutlak dinikahkan dengan laki-laki bukan Islam, baik laki-laki musyrik maupun ahl al-kitab. Dengan demikian dapat ditegaskan bahwa salah satu syarat sahnya pernikahan seorang wanita Islam.

Adapun pernikahan jenis kedua (laki-laki Islam dengan wanita bukan Islam) dapat dikelompokkan pada dua jenis, yaitu (1) Pernikahan antara laki-laki Islam dengan wanita musyrik dan wanita murtad, dan (2) Pernikahan antara laki-laki Islam dengan wanita ahl al-kitab. Terhadap jenis pernikahan yang pertama, ulama sepakat menyatakan bahwa hukumnya haram.

Seorang wanita murtad dari agama Islam dipandang tidak beragama, sekalipun ia pindah ke agama yang berkitab (ahl-al-kitab) samawi. Oleh karena itu, haram hukumnya menikahi wanita tersebut. ${ }^{22}$

Para ulama sepakat menyatakan bahwa seorang muslim haram menikahi wanita yang beragama Samawi, yaitu agama yang tidak memiliki kitab suci yang diturunkan Tuhan melalui Nabi yang namanya disebutkan dalam al-Qur'an. ${ }^{23}$ Setiap wanita yang tidak beragama Samawi, tidak halal dinikahi. Mereka tergolong kepada wanita-wanita yang disebutkan dalam ayat di atas.

Adapun hukum menikahi wanita ahl al-Kitab, ulama berbeda pendapat. ${ }^{24}$ Perbedaan ini disebabkan adanya teks yang

${ }^{22} \mathrm{Abu}$ Zahrah, al-Ahwal al-Sakhsiyah (Mesir: dar al-Fikr al-'Arabi, 1957), h. 116. Lihat juga Ibnu Qudamah, al-Mughni (Riyad: Maktabah alRiyad al Haditsah, tt.), h. 593.

${ }^{23}$ Abu Zahrah, Ibid., h. 112.

${ }^{24}$ Imam Abu Hanifah dan ulama Hanafiah serta sebagian ulama Hanabilah berpendapat, siapapun yang mempercayai salah seorang Nabi, atau kitab yang pernah diturunkan Allah swt., maka ia termasuk ahl al-Kitab, tidak terbatas pada komunitas Yahudi dan Nasrani. Dengan demikian, bila ada suatu kelompok yang hanya percaya kepada Zabur atau suhuf Ibrahim as dan Syits saja, maka ia pun termasuk dalam jangkauan pengertian ahl-alKitab. Bagi Imam Syafi'i, term ahl-al-Kitab dipahami sebatas Yahudi dan Nasrani keturunan Israil. Sedangkan bangsa-bangsa lain yang menganut agama Yahudi dan Nasrani tidak termasuk dalam term ahl-al-Kitab. Selengkapnya lihat M. Quraish Shihab, Wawasan al-Qur'an (Bandung: Mizan, 1996), h. 367. 
membolehkan menikahi wanita ahl al-Kitab. Sedangkan di sisi lain, terdapat pula hadis Ibn Umar di atas yang haram menikahi wanita ahl al-Kitab.

\section{Pendapat yang membolehkan}

Pendapat ini dipelopori oleh Imam Abu Hanifah, Imam Malik, Imam Syafi'i, Imam Ahmad ibn Hanbal dan pengikut mereka masing-masing. ${ }^{25}$ Adapun alasan-alasan yang mereka gunakan antara lain:

1. Firman Allah dalam QS. Al-Maidah (4): 5:
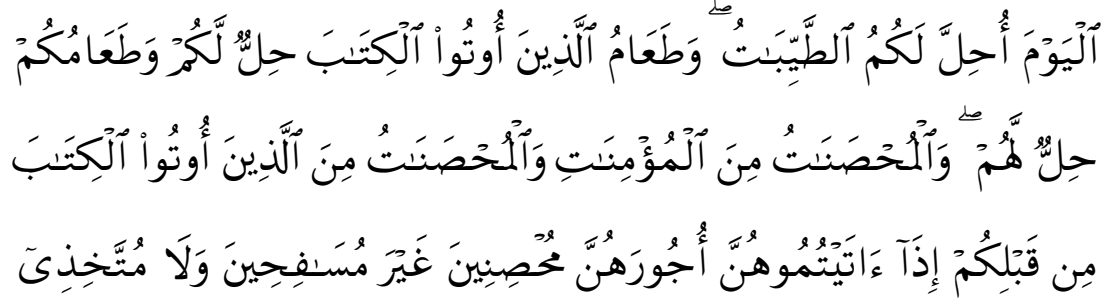

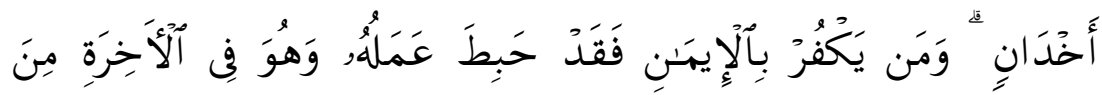

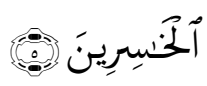

Terjemahnya:

Pada hari ini dihalalkan bagimu yang baik-baik. Makanan (sembelihan) orang-orang yang diberi Al kitab itu halal bagimu, dan makanan kamu halal (pula) bagi mereka. (Dan dihalalkan mengawini) wanita yang menjaga kehormatan diantara wanita-wanita yang beriman dan wanita-wanita yang menjaga kehormatan di antara orangorang yang diberi Al kitab sebelum kamu, bila kamu telah membayar mas kawin mereka dengan maksud menikahinya, tidak dengan maksud berzina dan tidak (pula) menjadikannya gundik-gundik. Barangsiapa yang kafir sesudah beriman (tidak menerima hukum-hukum Islam) maka hapuslah amalannya dan ia di hari kiamat termasuk orang-orang merugi. ${ }^{26}$

${ }^{25}$ Al-Jauziyah, Kitab al-Fiqh 'ala Madzahib al-'Arba'ah (Beirut: dar Ihya al-Turats al-Araby, 1979), h. 75.

${ }^{26}$ Departemen Agama RI, op. cit., h. 158. 
Ayat di atas menurut mereka jelas mengemukakan halalnya menikahi perempuan ahl al-Kitab.

(2) Sejarah telah menunjukkan bahwa beberapa sahabat Nabi pernah menikahi perempuan ahl al-Kitab, hal mana menunjukkan pula bahwa menikahi perempuan ahl al-Kitab itu halal hukumnya.

Para sahabat, kecuali Ibn Umar, membolehkan menikahi wanita ahl al-Kitab. Dalam praktek, ada diantara sahabat yang menikahi wanita ahl al-Kitab, seperti Thalhah ibn Ubaidiyah.

Menurut pendapat terkuat di kalangan Syafi'iyah perempuan ahl al-Kitab yang dihalalkan dinikahi tersebut adalah perempuan yang menganut agama Nasrani atau Yahudi sebagai agama keturunan dari orang-orang (nenek moyang mereka) yang menganut agama tersebut semenjak masa sebelum Nabi Muhammad diangkat menjadi rasul (yakni sebelum al-Qur'an diturunkan). ${ }^{28}$ Tegasnya orang yang menganut agama Nasrani atau Yahudi setelah diangkatnya Muhammad setelah menjadi Rasul atau setelah al-Qur'an turun, tidaklah dianggap ahl alKitab, karena pada ayat di atas terdapat kata min qablikum (dari sebelum kamu). Perkataan min qablikum menjadi qayyid bagi ahl al-Kitab yang dimaksud. Jalan pikiran Syafi'iyah ini mengakui ahl al-Kitab bukan karena agamanya, tetapi karena menghormati asal keturunannya.

\section{Pendapat yang mengharamkan}

Sahabat terkemuka yang memegang pendapat ini adalah Abdullah ibn Umar. Pendapat ini juga dipegang oleh ulama dikalangan Syi'ah Imamiyah. Adapun alasan yang mereka gunakan di samping hadis ibn Umar di atas, adalah sebagai berikut:

1. Firman Allah QS. Al Baqarah (2): 221 yang telah dikemukakan di atas.

2. Firman Allah dalam QS. al-Mumtahanah (60): 10:

\footnotetext{
${ }^{27}$ Abu Zahrah, op. cit., h. 113

${ }^{28}$ Ibrahim Hosen, Fiqh perbandingan (Jakarta: Yayasan Ihya Ulumuddin Indonesia, 1971), h. 203.
} 


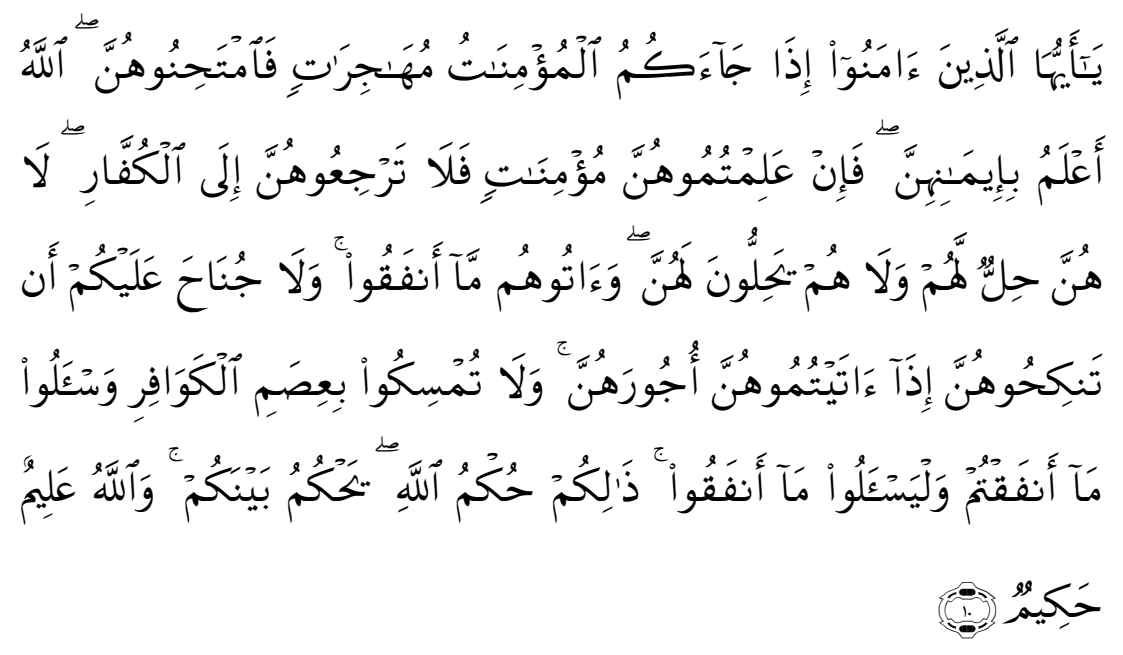

Terjemahnya:

Hai orang-orang yang beriman, apabila datang berhijrah kepadamu perempuan-perempuan yang beriman, maka hendaklah kamu uji (keimanan) mereka. Allah lebih mengetahui tentang keimanan mereka, maka jika kamu telah mengetahui bahwa mereka (benar-benar) beriman. Maka janganlah kamu kembalikan mereka kepada (suamisuami mereka) orang-orang kafir mereka tiada halal bagi orang-orang kafir itu dan orang-orang kafir itu tiada halal pula bagi mereka. dan berikanlah kepada (suami suami) mereka, mahar yang telah mereka bayar dan tiada dosa atasmu mengawini mereka apabila kamu bayar kepada mereka maharnya. Dan janganlah kamu tetap berpegang pada tali (perkawinan) dengan perempuan-perempuan kafir, dan hendaklah kamu minta mahar yang telah kamu bayar, dan hendaklah mereka meminta mahar yang telah mereka bayar. Demikianlah hukum Allah yang ditetapkanNya di antara kamu. Dan Allah Maha Mengetahui lagi Maha Bijaksana. ${ }^{29}$

Kedua ayat di atas jelas melarang laki-laki muslim menikahi wanita kafir atau musyrik. Ahl al-Kitab termasuk dalam kelompok orng kafir atau musyrik, karena orang Yahudi menuhankan 'Uzer dan orang Nasrani menuhankan Isa Ibn

${ }^{29}$ Departemen Agama RI, op. cit., h. 925. 
Maryam, dimana dosa syirik tidak diampuni Allah swt., jika mereka tidak bertaubat sebelum meninggal.

Adapun firman Allah pada surah al-Maidah ayat lima di atas, menurut golongan ini hendaknya diihtimalkan kepada pengertian bahwa kebolehan menikahi wanita ahl al-Kitab adalah pada masa perempuan-perempuan Islam sedikit jumlahnya.

Dari perbedaan di atas penulis melihat bahwa pada esensinya kedua pendapat di atas dapat dikompromikan. Hal ini dilakukan melalui tinjauan berikut ini.

1. Tinjauan Ushul Fikhi

Meskipun mayoritas ulama melegalkan terjadinya pernikahan antara laki-laki muslim dengan wanita ahl alKitab, tetapi status hukum taklifi-nya adalah mubah. ${ }^{30}$

Dalam kajian ushul fikhi,mubah adalah sesuatu yang diserahkan oleh Syari' kepada mukallaf untuk melaksanakan atau tidak. ${ }^{31}$

Dari definisi di atas, tegaslah bahwa hukum mubah bersifat takhyir (pilihan melakukan atau meninggalkan) yang bersifat netral antara perintah mengerjakan atau meninggalkan. Hal ini juga melatarbelakangi sebagian ulama menganggap mubah sebagai gambaran kekosongan hukum, sehingga dapat diisi (ditetapkan hukumnya) oleh mukallaf menurut situasi dan kondisi.

Hukum mubah yang bersifat netral ini, nantinya akan sangat tergantung dengan maslahat dan mafsadat. Ketika suatu perbuatan mubah tersebut yang bila dilakukan akan berdampak negatif (menimbulkan mafsadat), maka hukumnya dapat berubah menjadi haram.

2. Tinjauan siasat

Meskipun ada ayat al-Qur'an yang membolehkan menikahi wanita ahl al-Kitab, tetapi siasat saat ini tidak

${ }^{30}$ Muhammad Salam Madzkur, Mabahits al-Hukm 'Inda alUshuliyyah (Mesir: Dar al-Nahdhah al-'Arabiah, 1974), h. 32. Lihat pula Abdul Wahhab Khallaf, 'Ilm Ushul al-Fiqh (Kuwait: Dar al-Qalam, 1983), h. 130. Masih terdapat definisi mubah.

${ }^{31}$ Masih terdapat beberapa definisi mubah yang dikemukakan oleh para ahli ushul fikih, misalnya al-Syaukani yang mendefinisikan mubah dengan sesuatu yang apabila dikerjakan atau ditinggalkan tidak mendapat pujian. Lihat al-Syaukani, Irsyad al-Fuhul (Dar al-Fikr, tt), h. 6. 
dapat memberikan peluang kebolehan melakukan pernikahan tersebut.

Sebagai argumen dari tinjauan ini adalah ungkapan Umar yang disampaikan kepada para sahabat yang menikahi perempuan ahl al-Kitab.

Ceraikanlah mereka itu! Perintah Umar ini dipatuhi oleh para sahabat kecuali Huzaifah. Maka Umar mengulangi lagi perintahnya agar Huzaifah menceraikan istrinya. Lantas Huzaifah berkata: Maukah engkau bersaksi bahwa menikahi wanita ahl al-Kitab hukumnya haram? Umar berkata: Dia akan menjadi fitnah, ceraikanlah! Kemudian Huzaifah berkata lagi: Maukah engkau bersaksi bahwa ia adalah haram? Umar menjawab lagi dengan singkat ia adalah fitnah. Akhirnya Huzaifah berkata: Sesungguhnya aku tahu bahwa ia adalah fitnah, tetapi ia halal bagiku. Setelah Huzaifah meninggalkan Umar barulah isterinya ditalak. Lantas Huzaifah ditanya orang: mengapa istrimu itu tidak kamu talak di saat diperintahkan oleh Umar? Jawab Huzaiah: karena aku tidak ingin diketahui bahwa aku melakukan sesuatu yang tidak layak. ${ }^{32}$

Menikahi wanita ahl al-Kitab amat berbahaya, karena dikhawatirkan kalau-kalau suami akan tertarik hatinya, apabila telah memperoleh keturunan.

Mereka yang berpendapat membolehkan dan mengharamkan menikahi wanita ahl al-Kitab mempunyai pandangan yang sama bahwa kedudukan suami adalah pemegang pimpinan dan kendali dalam keluarga. Ia adalah teladan dalam pembinaan akhlak Islam. Ia harus mampu membina dan menunjukkan keluhuran agama Islam dalam lingkungan keluarga, khususnya kepada istrinya yang berbeda agama. Oleh sebab itu, sulit bagi laki-laki muslim saat ini untuk mewujudkan tugasnya bila pasangannya adalah wanita kitabiyah yang nyata-nyata mereka sudah sesat.

\section{Istinbat Hukum}

Melalui argumen yang digunakan di atas, maka dapat dianalogikan bahwa ketetapan hukum yang tepat untuk

\footnotetext{
${ }^{32}$ Ibnu Qudamah, op. cit., h. 590.
} 
diberlakukan saat ini adalah bahwa haram hukumnya bagi lakilaki muslim untuk menikahi wanita kitabiyah.

\section{PENUTUP}

Berdasarkan uraian yang telah dipaparkan di atas dapat ditarik beberapa simpulan, yaiu:

1. Hadis Ibnu Umar yang melarang laki-laki muslim menikahi wanita kitabiyah merupakan hadis mauquf yang berstatus ahad gharib. Tetapi, dari sisi kualitasnya hadis tersebut berstatus shahih. Oleh sebab itu hadis tersebut dapat dijadikan hujjah.

2. Ulama sepakat menyatakan bahwa haram hukumnya melangsungkan perkawinan antara laki-laki Islam dengan wanita kafir atau musyrik. Demikian juga halnya bahwa haram hukumnya bagi wanita Islam menikahi laki-laki non Islam, walaupun orang kitabiyah.

3. Bagi ulama yang tidak mengakui hadis Ibn Umar sebagai hujjah, mereka menggunakan beberapa ayat al-Qur'an dan argumen lainnya dalam menghalalkan perkawinan dengan wanita kitabiyah. Meskipun demikian, kebolehan tersebut amat bergantung dengan kondisi sosial politik, sehingga hukum tersebut dapat saja berubah menjadi haram.

4. Melihat kondisi sekarang, maka hadis Ibn Umar sangat tepat diberlakukan. Oleh sebab itu perkawinan laki-laki Islam dengan wanita kitabiyah haram hukumnya. Bila dengan wanita kitabiyah haram hukumnya, tentu lebih kuat lagi keharamannya terhadap wanita bukan kitabiyah. 


\section{DAFTAR PUSTAKA}

Al-Ashfahani, Al-Raghib. Al-Mu'jam al-Mufradat al-Alfadz alQur'an. Beirut: Dar al-Fikr, tt.

Badran, al-Ainain. al-Zawaj wa al-Thalaq fi al-Islam. Kairo: tp., tt.

Bavick, J. H. Sejarah Kerajaan Allah, pent. A. Simanjuntak. Jakarta: BPK Gunung Mulia, 1990.

Al-Bukhari. Shahih al-Bukhari.Beirut: Dar al-Fikr, 1994.

Cawidu, Harifuddin. Konsep Kufr dalam al-Qur'an Suatu Kajian Teologis dengan Pendekatan Tafsir Tematik. Jakarta: Bulan Bintang, 1991.

Dahlan, Abdul Aziz. Ensiklopedi Hukum Islam. Jakarta: PT. Ichtiar Baru Van Houve, 1997.

Departemen Agama RI. Al-Qur'an dan Terjemahnya. Semarang: Toha Putra, 1989.

Hosen, Ibrahim. Fiqh perbandingan. Jakarta: Yayasan Ihya Ulumuddin Indonesia, 1971.

al-Jaziriy. Kitab al-Fiqh 'ala Madzahib al-'Arba'ah. Beirut: dar Ihya al-Turats al-Araby, 1979.

Khallaf, Abdul Wahhab. 'Ilm Ushul al-Fiqh. Kuwait: Dar alQalam, 1983.

Madzkur, Muhammad Salam. Mabahits al-Hukm 'Inda alUshuliyyah. Mesir: Dar al-Nahdhah al-'Arabiah, 1974.

Qudamah, Ibnu. al-Mughni. Riyad: Maktabah al-Riyad al Haditsah, tt. 
al-Shan'ani, Muhammad ibn Ismail al-kahlani. Subul al-Salam. Riyad: al-Jami'ah al-Imam Muhammad ibn Su'ud alIslamiyah, $1408 \mathrm{H}$.

Shihab, M. Quraish. Wawasan al-Qur'an. Bandung: Mizan, 1996.

as-Shiddieqy, M. Hasbi.Pokok-pokok Ilmu Dirayah Hadis. Jakarta: Bulan Bintang, 1987.

Shalih, Subhi. 'Ulum al-Hadits wa Mushtalahuh. Beirut: Dar alFikr, 1988.

al-Thabari. Tafsir al-Thabari. Beirut: dar al-Fikr, 1984 .

al-Bayan fi al-Tafsir al-Qur'an. Beirut: Dar alMa'arif, tt.

al-Syaukani. Irsyad al-Fuhul. Dar al-Fikr, tt.

. Tafsir Fath al-Qadir. Beirut: Dar Ihya al-Turats al-Arabiy, tt.

Zahrah, Abu. al-Ahwal al-Sakhsiyah.Mesir: dar al-Fikr al'Arabi, 1957. 